\title{
Mapeando cerceamentos e o lugar da matança animal: o caso do Matadouro Municipal de Ponta Grossa em fins do século XIX.
}

\begin{abstract}
Mapping retrenchments and the place of animal slaughter: the case of the Ponta Grossa's Municipal Slaughterhouse in the late 19th century.
\end{abstract}

\author{
Lucas Vinicius Erichsen da Rocha ${ }^{1}$ \\ Alessandra Izabel de Carvalho ${ }^{2}$
}

RESUMO

O estabelecimento de um matadouro municipal na cidade de Ponta Grossa, no Estado do Paraná, se deu em estreita relação com reordenações do ambiente urbano nos finais do século XIX. À medida que discursos de modernidade e progresso passavam a fazer parte da ordem do dia, se tornava imprescindível repensar e disciplinar as práticas de matança animal que visavam o fornecimento de carne a população da cidade. Por meio da análise e entrecruzamento de trechos de códigos de posturas, atas da câmara municipal, plantas antigas da cidade e serviços contemporâneos de pesquisa e visual ização de imagens de satélite, buscamos apontar a possível localização do primeiro matadouro municipal da cidade de Ponta Grossa e analisar como era sua estrutura e funcionamento. O objetivo do artigo é contribuir para uma maior compreensão da historicidade das práticas de matança animal para o consumo humano demonstrando o vínculo entre a história dos matadou ros e a história ambiental urbana.

Palavras-chave: Matadouro. Ponta Grossa. História ambiental.

\section{ABSTRACT}

The establishment of a municipal slaughterhouse in Ponta Grossa, Parana State, occurred closely with the reordering of the urban environment in the late XIXth Century. As modernity and progress speeches spent to take part of the agenda, it became imperative to rethink and discipline animals slaughter practices that aimed to provide meat to the city's population. Through the analysis and crisscross of postures code snippets, minutes of the city council, old plants of the city and contemporary research

\footnotetext{
${ }^{1}$ Doutorando em História pelo Instituto de História da UFRJ. E-mail: lucaserichsen@outlook.com

${ }^{2}$ Doutora em História pela UNICAMP. Professora do Departamento e do Programa de Pós-Graduação em História da UEPG. E-mail: alessandra@uepg.br
} 
services and satellite images, we seek to pinpoint the possible location of the first Ponta Grossa's municipal slaughterhouse and analyze how it was its structure and operation. The paper aims to contribute to a greater understanding of the historicity of animals slaughter practices for human consumption demonstrating the link between the history of slaughterhouses and urban environmental history.

Keyword: Slaughterhouse. Ponta Grossa. Environmental history.

Eles não desperdiçam nada aqui, disse o guia, que então riu e acrescentou espirituosamente, contente de que seus amigos sem sofisticação entenderiam aquilo como se fosse de sua autoria: Eles usam tudo do porco, exceto o guincho ${ }^{3}$.

(Upton Sinclair - The Jungle)

A construção de um matadouro municipal em Ponta Grossa, no Paraná, ou ainda, a abertura de um espaço de matança centralizada de animais se deu em 1888 e refletia as várias mudanças que o espaço urbano experimentava. Até então as práticas de abate ocorriam em locais esparsos, geralmente improvisados. Mas os fatores modernidade e progresso se aliavam na constituição de ambientes citadinos vitais e civilizados de forma que o município não podia mais se abster de fiscalizar a produção da carne que era consumida pela sua população.

Eram tempos de normatização, de tentativas de disciplinarização, de forma que os últimos anos do século XIX também foram marcados pela publicação de um novo Código de Posturas. ${ }^{4}$ É possível inferir que a necessidade de atualizar as formas de ser, estar e participar da vida citadina estavam relacionadas com um discurso oficial que clamava o fim do Brasil Império e anunciava a instauração de uma República, em tese, não rural, contexto em que as posturas tiveram papel ímpar (PEREIRA, 1999).

As recentes posturas de Ponta Grossa evidenciavam a constituição de uma considerável vida urbana. É nesse contexto que o primeiro matadouro municipal de Ponta Grossa e novas práticas de matança passaram a figurar também nesse tipo de legislação, reconfigurando a geografia da morte animal, da prática das matanças e seus aspectos correlatos.

\footnotetext{
3 “They don't waste anything here", said the guide, and then he laughed and added a witticism, which he was pleased that his unsophisticated friends should take to be his own: "They use everything about the hog except the squeal." ${ }^{4}$ Encontram-se indicações de posturas anteriores aquelas do código de 1891 em uma ata da câmara municipal de Ponta Grossa e no livro Posturas municipais Paraná, 1829 a 1895 do Historiador Magnus Roberto de Mello Pereira. Referimo-nos ao novo Código semum ano específico de publicação porque na capa encontramos o ano de1891, ao passo que na última página do livro encontramos referências aos dias 26 de Dezembro de 1890, 21 de Janeiro de 1893 e 29 de Abril de1893. Uma possível explicação para tanto pode ser o fato de o código ser redigido de forma manuscrita e por ter recebido ao longos dos referidos anos novos artigos e decretos, ou seja, uma série de atualizações para dar conta da inconstância e da dinâmica das atividades na cidade. Desse modo, não embaralhamos os anos e nem reduzimos as diferentes temporalidades de redação do documento enquanto é possível dar-lhe sentido na narrativa.
} 
Ao analisar o código de posturas do final do século XIX, verifica-se que a vereança começava a versar mais intensamente sobre os matadouros e a relação desses locais com o município. Se agora havia a presença de um espaço de matança animal centralizada sob os auspícios da municipalidade, esta precisava ao mesmo tempo garantir a legalidade de uma série de aspectos ligados aos abates e das tentativas de alicerçar os poderes públicos e quem deles fazia parte mais intimamente.

Desse modo, é possível rastrear o que seriam desatinos e tentativas de lidar com os abates dentro das novas configurações da cidade com a presença de um matadouro municipal. Alguns desses indícios referem-se à presença de armas no perímetro urbano e sua provável relação com o local de matança animal.

Título 13

Armas proibidas

Art 86 São armas prohibidas todo o instrumento cortante, perfurante, contundente e arremessante.

Art 87 São armas defesas, cujo uso as autoridades poderão permittir, espada que não tenha menos de 10 centímetros de folha, pistola que não tenha menos de 25 centímetros de cano e faca de ponta.

Art 88 As autoridades policiais poderão conceder uso das armas, de que trata o artigo antecedente mediante fiança nos termos do Cap 8 art 103,105, 107 e seguinte do código do processo criminal no que forem aplicáveis; isto porem quando o uso das armas for para fora das povoações, mas sendo dentro dellas, além da fiança, o impetrante justificará com duas testemunhas, ao menos, que sua vida corre perigo. Art 89 São armas que se podem haver sem licença

Todos os instrumentos próprios das artes e officios, trazendo o em ocasião em que se vae ou vem de exercitar as mesmas artes e officios, e bem assim bengalas sem estoques, que não tenhão mais de um metro de altura e 6 centímetros de diametro, aguilhada e facas aos guiadores de carros, não tendo aquellas menos de 2 metros de comprido e 8 centímetros de diâmetro, bolas, laços e facas aos campeiros, no exercício do campo, faca e azorrague ao almocreve e faca ao carniceiro, quando no matadouro ou açougue. (Código de posturas 1891-1893, grifo nosso).

A intenção era superar e, consequentemente, abolir uma cultura que era diretamente ligada aos costumes coloniais e rurais, então incompatíveis com o universo modernizante. Assim, no final do século XIX a municipalidade buscava tratar intimamente dos matadouros 
e sobre o trabalho dos carniceiros. Nesse caso, a concessão de haver sem licença o porte de facas se dava não somente em uma esfera de choques culturais entre novos e velhos valores, mas também na complexificação da interface entre sociedades humanas e natureza, algo que teve sua emergência decorrente da difusão dos poderes públicos sobre as práticas de matança animal, algo que antes não parecia ser tão pertinente.

O mesmo livro de posturas ainda destaca outras reconfigurações exigidas pela presença de um matadouro municipal:

Título 11 - Sobre economia, aceio dos açougues e matadouros Art. 81 Só no matadouro público ou particulares, com licença da intendencia se poderão matar e esquartejar reses para consumo público, os contraventores soffrerão multa de 10:000.

Art. 82 Os carniceiros que não conservarem todo o aceio possível nos seus açougues tendo a carne pendurada e bem limpa, ou que consentirem carnes podres ou qualquer imundice dentro ou junto delles, soffrerão a multa de 10:000 por cada infração.

Art. 83 Todo o dono de açougue que concentir que a pessoa que não more nelle, venda em sua casa carne ou outro qualquer objeto prejudicando assim o açougue municipal soffrera multa de 20:000 [?] ${ }^{5}$ do imposto. (Código de posturas 1891-1893)

O caráter punitivo é de fato o eixo norteador das posturas, tal como é recorrentemente apontado nos mais diferentes artigos do documento. O Artigo 82 refere-se à conservação e condições de higiene da carne, bem como versa sobre as formas disciplinadas de vendê-la. A infração do artigo em questão incorreria em uma multa significativa, pois dizia respeito ao não cumprimento de um dos principais aspectos que vinham na esteira do projeto modernizador e civilizador em desenvolvimento na cidade, ou seja, a limpeza dos espaços públicos.

O Artigo 83 chama a atenção não apenas pelo alto valor da multa ${ }^{6}$ mas principalmente por ser muito mais direto ao explicitar seu preponderante objetivo que era o de proteger o comércio do açougue municipal. Ora, esses dois artigos revelam uma estreita relação com a constituição e manutenção do poder público. Consentir que um não açougueiro também tivesse lucros com a venda de carne era uma agressão à prerrogativa dos afazeres do ofício estabelecida pelo município. Assim, tal proibição resguardava não somente os princípios de um projeto de modernidade e civilidade, mas principalmente o fortalecimento do poder

\footnotetext{
${ }^{5} \mathrm{O}$ uso do sinal de interrogação indica partes ilegíveis do documento.

${ }^{6}$ As multas nesse código variam de 5/8 a 30:000 réis.
} 
municipal e de seus representantes que inclusive encabeçavam grande parte desse projeto. $\mathrm{Ou}$ seja, os poderes públicos buscavam legislar no achatamento dos choques sociais e culturais, enquanto trabalhavam essas tensões sempre em favor de garantir e manter as relações de forças favoráveis para eles mesmos.

O Artigo 81 também permite visualizar as tentativas de controle por parte do poder público, mas, nesse caso, em relação aos sujeitos envolvidos na morte e esquartejamento de animais para consumo. Isso é apontado não somente ao proferir a necessidade de uma licença de intendentes, mas pelo fato de penalizar e classificar como contraventores aqueles que não estivessem de acordo com as decisões da vereança. Isso dizia respeito, muito provavelmente, à manutenção das antigas práticas de matança, pois se alguns animais ainda eram mortos em quintais antes da abertura do matadouro público em 1888, em pouco mais de dois anos dificilmente a população já teria transformado as práticas por definitivo.

É interessante notar os exercícios de poder sobre os corpos humanos e de animais nãohumanos, caracterizados principalmente pela vigilância e punição da municipalidade sobre as formas e para com os locais de matança das reses. Um dos possíveis desdobramentos de tais aspectos diz respeito à resistência em relação às alterações que estavam sendo impostas no ambiente de trabalho dos abatedores, algo que foi bastante presente no contexto europeu e gerou graves consequências, como aponta Lukasz Nieradizk ao detalhar o caso da construção do matadouro municipal de Veneza e a reação dos trabalhadores do ofício:

\footnotetext{
Eles geralmente interpretavam a obrigação de abater em Saint Marx ou a introdução de novas ferramentas de matanças como uma ilegítima intervenção em suas tradicionais competências [...]. Alguns deles experimentaram esse processo como uma desistência e em alguns casos alguns abatedores cometeram até mesmo suicídio. ${ }^{7}$ (NIERADZIK, 2012, p. 14, grifo nosso).
}

Sobre essa característica da resistência dos trabalhadores, algo similar ocorreu em Londres, um pouco antes da regulamentação dos matadouros em 1875. Mesmo ainda não sendo efetiva a presença de um matadouro público, já existiam esforços das autoridades locais na transformação das práticas daqueles que trabalhavam na matança animal. No caso londrino, nota-se que a pouca fiscalização ocasionou um comércio de carne pouco asseada. A astúcia dos sujeitos envolvidos, tanto no aspecto de garantir exceções quanto em contornar a frágil regulamentação e inspeção local, os levava a infiltrar na cidade carne imprópria para consumo, já sob a forma de tortas e outros produtos:

7 Todas as traduções aqui apresentadas são livres e de nossa responsabilidade. 
Os abatedores de Londres, entretanto, defendiam obstinadamente seu direito de matar onde e como eles queriam, o que foi garantido por uma exceção no Metropolitan Buildings Act's de 1844 na cláusula de negócios nocivos. A falta de regulamentação e inspeção de vacas, a limitada manutenção de registros e vagões sujos claramente ajudaram na disseminação da doença do gado em 1865. Animais doentes geralmente eram vendidos de forma rápida para inescrupulosos abatedores, e a carne geralmente "polida" para disfarçar aspectos doentes, ou picadas e convertidas em salsichas ou tortas e despachadas sorrateiramente nas cidades durante à noite em carros a prova de som. Alguns matadouros se especializaram no processamento de carne insalubre, e em 1855 circularam rumores que um elefante de circo morto teria sido transformando em salsichas depois de ter sido vendido para um knacker não muito exigente. (OTTER, 2006, p. 528, grifo nosso).

Partindo desses apontamentos e pensando paralelamente o caso de Ponta Grossa, é possível depreender que a não efetivação da transformação das práticas de matança na cidade tenha desencadeado a necessidade de atualizações das normas para os abates. Mesmo com um código de posturas em vigor, era preciso tornar as normas mais severas, conforme nota-se em uma ata da câmara de vereadores no início de 1894:

Foi pelo prefeito apresentado os seguintes artigos para regulamento do matadouro.

Art $1^{\circ}$. É expressamente proibido abater gado vaccum, suíno e rezes fora do matadouro publico para ser vendido como carne verde ${ }^{8}$ na cidade e sua imediação sob pena de multa de $\mathbf{2 0 . 0 0 0}$ por cabeça ao dono da res morta, de 10:000 a quem for encontrado vendendo-se à carne da mesma.

Art $2^{\circ}$. A matança só será feita em res descançada sob pena de 10.000 de multa.

Art $3^{\circ}$. No matadouro se cobrará

$1^{\circ}$ por uma res abatida 2:000

$2^{\circ}$ por uma [?] de carneiro 5.000

Art $4^{\circ}$. As multas serão cobradas pelo procurador da Camara recebendo o fiscal $25 \%$ de cada multa e $25 \%$ o procurador.

Artigo $5^{\circ}$. Revogão-se as dispersões em contrário

\footnotetext{
${ }^{8}$ Carne verde era toda carne recém abatida, ou seja, eram os talhos frescos e/ou salgados destinados para venda e
} consumo imediatos. 
Paço da camara 10 de março de 1894. Entrando em discussão cada artigo de [?] forao approvados unanimemente mandando afixar editaes. (Ata de 10 de março de 1894).

Nota-se pelo Artigo $1^{\circ}$ a forma enfática da proibição de abates, agora ilegais, fora do matadouro municipal. O fato de o prefeito levar à discussão esses artigos, e usar de tal advérbio "expressamente" denota ainda que, sob esses aspectos, a legislação vinha sendo ineficaz na manutenção das posturas do município e havia a necessidade de que tal infração fosse tratada com maior rigidez. Ou seja, a ordem discursiva utilizada para a construção e ordenação da sociedade pontagrossense precisava ser mais acentuada para que a sua prática fosse materializada.

O Artigo $2^{\circ}$ enfatiza que a matança seria feita somente em res descansada, uma preocupação que não aparece anteriormente em nenhum documento averiguado. De todo modo, o descanso dos animais se fazia necessário não pelo fato de preocupações com o bem estar dos animais, mas por conta de tornar a matança menos complicada. Isso porque, desde o transporte até a chegada ao matadouro, os bois, porcos e carneiros ficavam agitados, nervosos, famintos e com sede, o que dificultava o trabalho no matadouro.

\section{Estrutura e funcionamento do edificio}

Nessa mesma ata de 10 de março de 1894 rastreiam-se mais pistas de como era o matadouro municipal, o estado em que se encontrava e também características sobre a forma que a cidade de Ponta Grossa vinha tomando:

\section{Matadouro Público}

Este edificio esta em completo estado de estrago que confronta a alma de quem a elle se derige, precisa-se para com urgencia limpando-o todo, caialo, fazer uma nova porta com boa e forte fechadura, consertar suas mangueiras, limpar os corres de esgoto e igualmente o tanque, retelhalo e fazer-se uma mangueira propicia para-a matança de porcos, faser com que o vagonete seja movido e tudo mais que se julgue preciso a este edifício que orçamos na quantia de 400.000 .

[...] 
Entrando em discussão foi unanimemente approvado mandando-se affixar editaes para as obras da rua de Santa Luzia e Matadouro, chamando-se assim concorrentes e mais serviços do parecer.

[...]

Indicamos que esta Camara contracte com o cidadão Alberto [?], para na qualidade de agrimensor incumbir-se de fazer o alinhamento das novas ruas desta cidade, em vista de quase todas se acharem fora da regra e alinhamento.

[...]

Posta em hasta publica as rendas do Matadouro forão ellas arrematadas até 21 de Dezembro do corrente ano por Frederico [?] por 560:000, mandando-se [?] obrigando a entrega-lo como receber concertado. (Ata de 10 de março de 1894, grifo nosso)

Percebe-se que existia uma grande preocupação com as condições de funcionamento, mas sobretudo com a própria aparência daquele edifício, o que poderia causar certo constrangimento a uma cidade que ganhava cada vez mais visibilidade e destaque no cenário paranaense por conta da inauguração das ferrovias. ${ }^{9}$ Essa nova configuração apresentou uma urgente necessidade de novos ordenamentos espaciais e de racionalização do ambiente urbano em conta do aumento na circulação de pessoas e pela presença da grande estrutura ferroviária. Ao incumbir-se de contratar alguém para fazer o alinhamento das novas ruas da cidade, a câmara de vereadores visava claramente um reordenamento do espaço semelhante ao que ocorrera em outras cidades.

Reservemos, entretanto, as circunstâncias em que se encontrava o matadouro na primeira metade de 1894 e regressemos rapidamente até janeiro de 1893, com uma ata que elucida ainda mais as condições em que se davam a matança:

Passando ao Matadouro Publico, melhor diremos o que vimos. Principia pelas portas que não tem fechadura, a coberta falta em dois ou três lugares, estando apodrecendo a madeira. O quarto em que guardarão as ferramentas e coisas esta sem fechadura e muito sujo. $\mathrm{O}$ tablado com carretilha em que se abatia as reses não funciona mais por ter estragado, encontrando dentro do matadouro um pau em forquilhas em que passão o laço para sangrar as reses, caindo as mesmas no chão

9 Nesse momento da cidade, só havia o ponto de terminal da Estrada de Ferro do Paraná,inaugurado em 1893. Para mais detalhes sobre os desdobramentos e o contexto da implantação das ferrovias ver Na Trama dos Trilhos: Cidade, Ferrovia e Trabalho em Ponta Grossa - PR (1955 - 1997), tese de doutoramento defendida por Rosangela Maria Petuba, na UFSC, em 2011. 
estando imundo o lugar, as carretilhas de içar estão estragadas estando fincado dentro da casa dois [?] para este serviço. A mangueira não oferece segurança para guardar o gado que tem de abater-se lá. Esta podre na [?], a mesma não tem portão ou porteira para fechar, sendo preciso ficar assim alguns [?] que tirão da reses. Encontramos a mangueira pegada que calculamos que seria antigamente de fechar as reses, sem fechadura em todos os lances, estando novamente as tranqueiras. $O$ esgoto que sobra as aguas de dentro do matadouro esta entupido, ficando depositado o estrume e sangue na beira da casa, o que poderá desenvolver qualquer epidemia com o calor que tem feito, visto estarmos no tempo em que muito se descobrem febres de todo o caso. Falta um pontilhão em frente a porteira da mangueira, na vala que essa para esgoto das águas que occupão dentro do Matadouro. Pedimos desculpa se tiver passado em nossa revista qualquer coisa que prejudique esta Camara e as [?] Municipaes, esperando que tornem a deliberação de melhorar tudo quanto expomos, e acabar com os atrasos que tem dado-se nas [?] passadas, visto nosso município estar prosperando e ser de muito futuro. [...]

Entrando em discussão, tendo fallado sobre a matéria os Senhores Camaristas Peixoto Severo de Souza e Antunes de Almeida, este ultimo pedio que se concedesse ao arrematante praso ate o fim do corrente mês para apresentar o matadouro limpo e concertado, assim como também limpo e concertado o mercado, e que elle a isso se obrigara. (Ata de 19 de Janeiro de 1893).

Passado mais de um ano entre ambos os documentos, a situação parecia não ter avançado, mesmo após a câmara de vereadores ter concedido um mês para regularizar a situação do matadouro, conforme consta na ata de 1893. Por outro lado, pode-se imaginar que os lucros do matadouro e do mercado municipal para o arrematante não poderiam ser dos menores, visto que a câmara estipula também o concerto e limpeza do mercado em igual prazo.

Desde o início de 1893, ou seja, passados mais de quatro anos desde a instalação do matadouro municipal, as condições físicas do prédio já não correspondiam a Ponta Grossa que vinha sendo idealizada.

Esse ideal parece tomar mais forma ainda no discurso sobre o projeto que permeava a cidade. Na ata de 19 de janeiro de 1893, logo ao fim da longa exposição sobre o estado do matadouro, é enfatizado que o município estava progredindo e seria de "muito futuro". Tal ênfase, no entanto, chama a atenção pelo fato de soar como um alerta à atuação do próprio 
poder público. A crueza da forma em que o matadouro é apresentado - que qualquer pessoa poderia verificar ao passar próximo do edifício -, poderia vir a prejudicar a própria câmara, inclusive na ausência de observações, como é relatado em ata.

A descrição do estado em que se encontrava o matadouro tem tons de um diário de campo. A impossibilidade de fechar as portas do matadouro por conta da ausência de fechaduras nos proporciona imaginar algumas situações. Uma delas é que, por não ser possível fechar as portas, a presença de pessoas que não trabalhavam no local deveria ser constante, inclusive fora do horário de funcionamento.

Desse modo, não só as precauções de higiene se viam em risco, bem como o matadouro nunca cessava de ser um espaço público, no sentido mais amplo do termo. Ao mesmo tempo, havia a possibilidade de os transeuntes da cidade poderem assistir a matança de bois, carneiros e porcos sem maiores dificuldades ao se aproximar do matadouro. $O$ desagradável espetáculo era algo bem aquém do que se esperava de um prédio recente e de uma destacada cidade paranaense. Entretanto, essa amarga receptividade do matadouro público da cidade guardava suas similaridades com os matadouros particulares de Londres, conforme notamos na imagem a seguir:

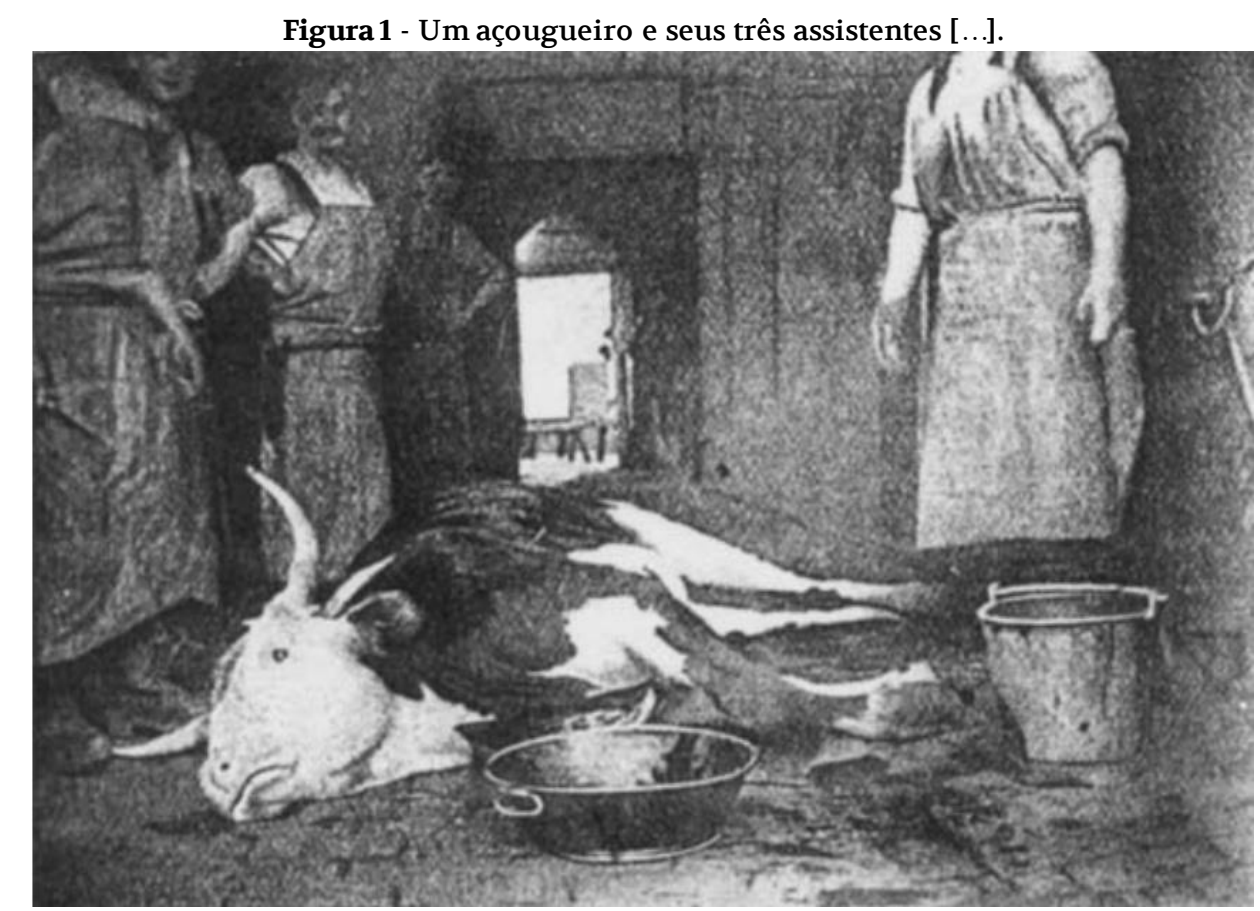

Fonte: Maclachlan (2007, p. 244).

Nota-se ao fundo da imagem, próximo à porta, duas cabeças olhando para dentro do local. As quais são referidas na descrição original da figura como sendo de dois pequenos 
garotos, "uma prática abominada pelos humanitaristas britânicos que acreditavam que a matança tinha uma influência brutalizante sobre mulheres e crianças" (MACLACHLAN, 2007, p. 244).

Façamos um pequeno parêntese por conta de nossas necessidades narrativas. Deve-se notar que os matadouros londrinos mantiveram-se sob os auspícios de particulares até o fim da segunda década do século $\mathrm{XX}$, ainda que tenha havido o fechamento de mais de 1000 matadouros entre os anos de 1873 e 1897 (MACLACHLAN, 2007, p. 247). E, embora as fiscalizações veterinárias tenham sido efetivadas somente em meados da década de 1960 (MACLACHLAN, 2007, p. 253), já existiam pressões de reformadores e de órgã os preocupados com a saúde pública desde as últimas décadas do século XIX para a construção de um matadouro público em Londres. Enquanto eram gestadas as proposições sobre a construção de matadouros municipalizados e centralizados, era criado, em paralelo, o The National Federation of Meat Traders' Associations ${ }^{10}$ (NFMTA).

O sucesso em adiar a criação de matadouros públicos em Londres decorreu do papel político da organização que tinha seus membros encorajados "a participar de reuniões públicas organizadas por humanitaristas e vegetarianos para se oporem aos reformadores e defender o ofício de descrições incoerentes" (MACLACHLAN, 2007, p. 250). Esses embates públicos em torno da carne já eram visíveis desde o final do século XIX na capital da Inglaterra e em outros grandes centros urbanos, tal como se deu com a instituição do famoso matadouro de La Villete, em Paris, e com o processo experienciado posteriormente em Chicago, em meados da década de 1900.

Do ponto de vista teórico-metodológico, a comparação dos casos da capital da Inglaterra e de Ponta Grossa impossibilitam uma tarefa narrativa estruturada de forma linear, como se simplesmente houvessem encadeamentos prováveis de acontecimentos que poderiam ser encontrados invariavelmente em quaisquer processo referente à passagem dos "protomatadouros" - que eram matadouros que ainda não trabalhavam com matança animal concentrada, nem racionalizada ou disciplinarizada, que funcionavam sem os devidos cuidados com a higiene e em nada preocupados com o sofrimento das reses - para os matadouros (ERICHSEN; CARVALHO, 2014).

$\mathrm{Na}$ verdade, temos aqui um dos aspectos que nos levam a relatar o matadouro público de Ponta Grossa com seu destaque enquanto possuidor de especificidades e como emergência do diferente no tempo. Ora, do mesmo modo em que o espaço de matança animal centralizada pontagrossense era público e tinha características próximas daquelas encontradas em La Villete, na França, cujo caráter das matanças já era centralizado, o matadouro público de Ponta Grossa ainda mantinha dinâmicas típicas dos "protomatadouros".

10 Em livre tradução, Federação Nacional das Associações dos Comerciantes de Carne. 
Certamente não era só em função das portas que não fechavam que o matadouro municipal ainda esboçava faces das antigas formas de matar animais para consumo humano. $O$ edifício do matadouro não contava mais com a carretilha ${ }^{11}$ e seu tablado, itens que deveria transportar o corpo de um animal por boa parte do processo de abate. Ao cruzarmos as informações das fontes com alguns relatos sobre matadouros, é possível deduzir que essa carretilha com tablado (também referida na ata de 1894 como vagonete) deveria ter similaridades com a que havia no matadouro municipal de Campinas, no final do século XIX, conforme notamos na imagem a seguir:

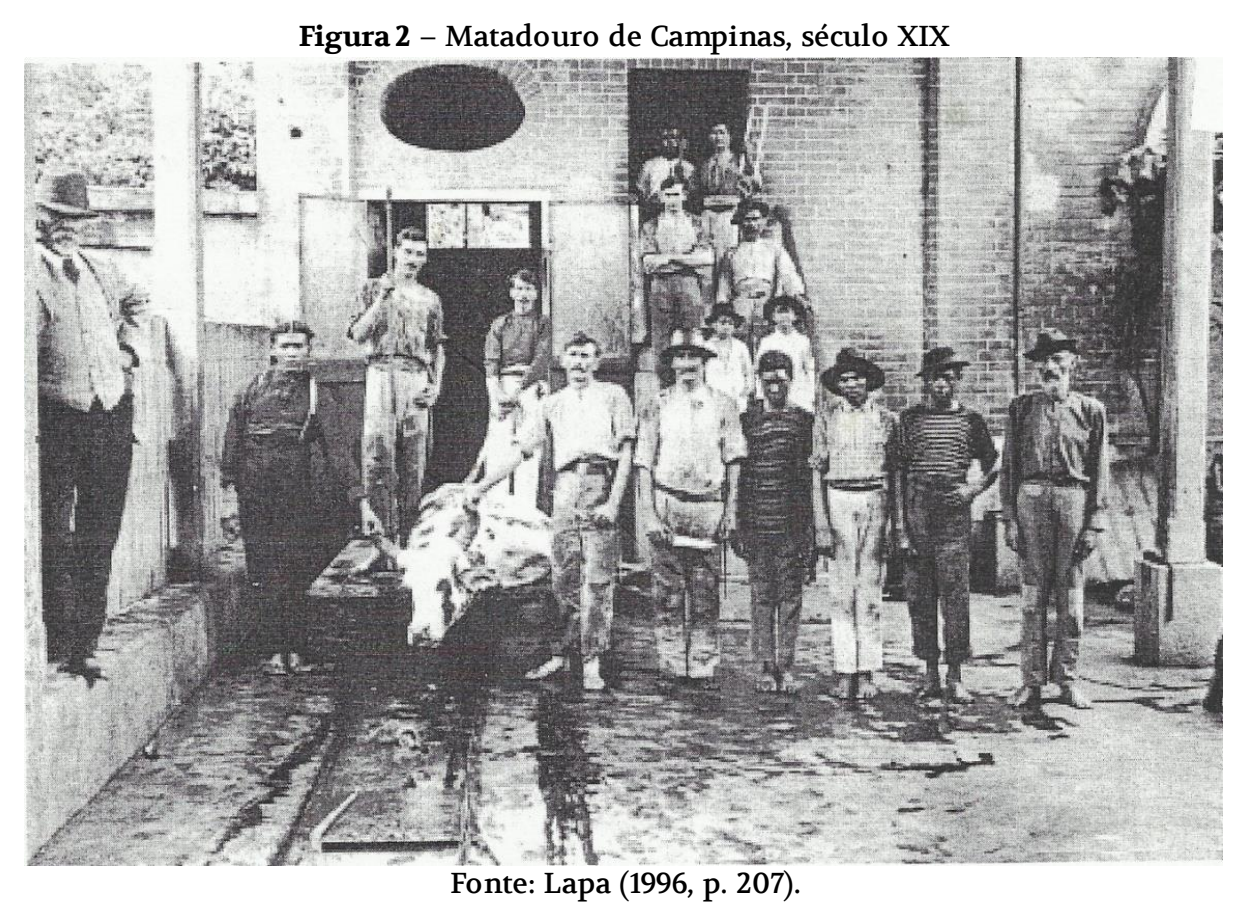

Nota-se que o caminho que a carretilha deve seguir é por meio de um trilho simples e que a morte do boi era realizada antes de entrar no prédio de fato. Nesse espaço notamos a presença abundante de sangue no chão e o detalhe, também apontado na descrição original da foto, de todos nesse piso estarem descalços.

Como já destacamos anteriormente em relação à questão das ferrovias, aqui podemos ressaltar mais uma vez o quanto trilhos e vagões tratavam-se de um dos principais bastiões do capitalismo modernizador. Esse aspecto se conecta também à história dos matadouros,

\footnotetext{
${ }^{11} \mathrm{O}$ termo carretilha é mais usual para instrumentos de pesca ou como um sinônimo para se referir as chamadas polias encontradas em roldanas (mecanismos que permitem levantar cargas com muito menos força do que normalmente seria aplicado, através de um sistema de cordas e rodas). É necessário destacar isso, pois, para o nosso caso, o termo carretilha faz referência ao diminutivo de carreta e também como instrumento de içar.
} 
pois naquele momento, vagonetes e pequenos trilhos começavam a marcar sua atuação, ainda que discreta, na historicidade da matança animal para consumo humano.

De toda maneira, o fato da carretilha do matadouro público de Ponta Grossa não funcionar deveria fazer com que o estabelecimento retomasse as práticas anteriores do abate e dos processos correlatos. Se esse pequeno protótipo de uma linha de desmontagem não funcionava como deveria, não é difícil depreender que os momentos de matança, sangria e esquartejamento encerravam-se todos no mesmo espaço.

Algo que avigora esse teor percebido no matadouro de Ponta Grossa é que, conforme nota-se na ata de 1893, no momento da sangria utilizavam-se de técnicas de improviso. Notável é o caso das forquilhas que garantiam a sustentação de um pau que, utilizado para sustentar reses por meio de um simples laço, não aguentava o peso de bois, carneiros e porcos, fazendo com que os corpos dos mesmos caíssem no chão tornando o matadouro imundo.

A ausência de um pontilhão sobre a vala onde escorriam todos os resíduos das matanças só incrementava o quadro de como era transitar no matadouro público de Ponta Grossa. Não sendo o bastante, havia ainda uma mistura da água utilizada para limpeza da matança que, por conta do edifício estar com o esgoto entupido, ficava acumulada no entorno do matadouro junto com as fezes dos animais que ali passavam e do sangue dos mesmos depois que eram sangrados. A preocupação evidente na ata é com a proliferação de doenças e um possível desenvolvimento de epidemias por conta do calor que fazia na época, apreensão aliada com o fato de que se estaria em um "tempo em que muito se descobrem febres de todo o caso" (Ata de 19 de Janeiro de 1893).

Portas sem fechaduras e resíduos por toda a volta do local de matança animal centralizada de Ponta Grossa era o cenário apresentado pelo primeiro matadouro público da cidade poucos anos após a sua inauguração. Se, por um lado, parecia que a modernidade capitalista chegava na cidade de trem, por outro, a morte de animais para consumo humano continuava conjurando faces pré-modernizadas. Todo esse panorama gera semelhanças com o que Chris Otter (2006) destaca sobre o caso da cidade escocesa de Stirling, cujo matadouro ficava no alto da cidade, fazendo com que o sangue escorresse morro abaixo, lançando uma espécie de mácula indigna que marcava o local com diferentes colorações:

Em Stingling, Chadwick lembrava, “o matadouro é situado próximo ao topo da cidade, e o sangue de lá escoa nas ruas abaixo". Os matadouros conjuravam uma sombra mórbida, ou "mancha moral", colorindo caracteristicamente as áreas ao seu redor. Crianças se reuniam para assistir a sangrenta luta entre matadores e a besta. Durante os 
assassinatos de Jack, o estripador, um ministro de Londres demandou o fechamento de todos os matadouros de Withechapel (OTTER, 2006, p. 527).

O sangue sempre apareceu "como a figura central de muitas formas públicas de sacrifício no coração das cidades" (SEGATA, 2013, p. 61), relação que vinha sendo evitada na constituição da carne para consumo humano desde o fim do século XIX.

Desse modo, todos esses aspectos merecem destaque para notar a falta de ação com que a questão do matadouro era tratada em Ponta Grossa, pois como observamos na ata de 1894, as requisições são diretamente ligadas a tudo aquilo já observado no ano anterior. Assim, fala-se em limpar todo o local com urgência, consertar as portas e mangueiras, limpar o esgoto, retelhar, mover o vagonete e uma referência até então inédita que é a de caiar o edifício, para evitar a proliferação de fungos por meio da pintura com cal, o que necessitaria já de uma vultosa quantia em dinheiro.

No final do século XIX, e mesmo com as constantes atualizações das posturas na quilo que dizia respeito ou que era correlato ao processo de matança, pareciam ainda existir nós a serem desatados para que Ponta Grossa embarcasse naquela desejosa previsão de 1893 que falava sobre a pretensa prosperidade da cidade. No final do ano de 1897, por exemplo, uma das discussões da vereança municipal denota como ainda se estava distante de uma cidade idealmente preparada para o século XX:

Foi lida a indicação seguinte: Indico que alem do que dispoem as posturas municipaes em vigor seja de hoje em diante fiscalizado energicamente pelo respectivo fiscal dessa Comarca o seguinte: $1^{\circ}$ açougues que não se acham conforme no estado de aceio vendendo-se em algum carne de 3 dias: $2^{\circ} \mathrm{A}$ iluminação publica desta cidade que é feita em pessimas condições e reclamada por parte da população: $3^{\circ}$ As ruas da cidade que muitas delas acham-se sujas e até encontra-se aves mortas como galinhas, corvos bem como gatos etc, etc. $4^{\circ}$ finalmente será punido com 5 ou 10.000 reis de multa o respectivo fiscal pela falta de cumprimento de qualquer exposto. (Ata de 20 de dezembro de1897).

Novamente evidencia-se a ocorrência de atos que contrariavam as almejadas políticas da cidade. Havia a necessidade de fiscalização para garantir a execução das posturas municipais, demonstração do duplo movimento constituído pelo aumento da abrangência 
dos poderes, algo que corporificava uma fragilidade que pode ser percebida da seguinte forma. O imperativo da fiscalização trazia a efeito a necessidade de nomear um funcionário para fiscalizar. O fiscal por sua vez, que era parte integrante da máquina pública, tinha como incumbência garantir a entrada de dinheiro aos cofres públicos ao penalizar contraventores, tarefa que, ao mesmo tempo, pretendia garantir a efetivação da civilidade.

O vigor com que deveria ser levada a vigilância é destacado sob a urgência de cuidar da iluminação da cidade e, mais especificamente ao nosso caso, as condições da carne dos açougues e os corpos de aves e gatos nas ruas. Isso destacado, figuram indiretamente os bois, carneiros e porcos mortos no matadouro ao ser revelado que suas carnes eram vendidas após três dias da matança, o que significava em más condições. Desse modo, a presença daqueles animais ainda era sentida para além do espaço de matança centralizada. Como não existem referências às maneiras de conservação das carnes naquele período da cidade, não seria difícil imaginar a putrefação das carnes competindo com odores e aparências desagradáveis dos corpos de galinhas, gatos e corvos, potencializando ainda mais a sujeira das ruas e, consequentemente, da cidade.

A ata ainda permite destacar algo interessante à referida frágil abrangência dos poderes públicos que é a instauração de uma multa para aquele que deveria fiscalizar e consequentemente multar. Ou seja, seria fiscalizado e poderia ser penalizado quem deveria penalizar. Os conflitos que haviam entre os poderes instituídos e outras esferas da sociedade se faziam sentir internamente em um campo pouco amigável, como podemos perceber pelo teor do final da ata.

Os anos finais do século XIX, quando analisados por meio da documentação da câmara de vereadores, permitem a visualização de novas taxas para alguns itens comercializados:

[...] por cada couro de gado 200rs, por cargueiro de palmito 500rs, por cada 15 kilos de lã 500rs, por carneiro abatido no matadouro 500rs, por carneiro vendido no mercado, 500rs, por cargueiro de cal100rs, [...]. (Ata de fevereiro de 1898).

Entre os itens relevantes para nosso trabalho, devemos notar a taxação de artigos cuja presença anteriormente não era nem brevemente referida. Nesse caso, é considerável a presença de uma taxa para cada couro de gado. Ainda mais interessante é que o valor era por unidade e não quilograma. É significativo também um valor referente a cada 15 quilogramas de lã. E se ainda existisse alguma dúvida para a origem da cal necessária para a caiação do matadouro, o documento de 1898 destaca a presença desse item na cidade e sua provável 
abundância vista a necessidade de taxação. Assim sendo, podemos dizer que, do ponto de vista financeiro, era interessante aproveitar os incrementos que vinham sendo efetivados na cidade para arrecadar mais e, assim, alimentar os cofres públicos.

Com relação ao valor do couro de gado, notam-se os primórdios da utilização daquilo que anteriormente eram subprodutos das matanças e que normalmente eram jogados fora, processo que é levado às últimas consequências com a industrialização do abate no início do século XX. Entretanto, para o caso de Ponta Grossa, o surgimento desse subproduto na documentação da cidade pode ter ligação com o aumento de pessoas vindas de outras regiões, que traziam novas formas de tratar a matança e seus efeitos.

Por mais que a abertura de curtumes ou o aumento da demanda de carne para consumo não sejam os objetivos e nem os principais tópicos do presente trabalho, é válido apontar algumas questões que fazem referência ao principal assunto. Com isso, o primeiro tópico é a possibilidade de inferir que a abertura de curtumes na cidade proporcionou um espaço onde a municipalidade encontrou mais um meio pelo qual poderia exercitar seus poderes e angariar arrecadações. Ora, se até a pele dos bois seria aproveitada e outros iriam lucrar com isso, o município também deveria garantir sua cota, ainda mais se os bois e carneiros fossem do rebanho municipal.

Da mesma forma, vale ressaltar brevemente que um segundo tópico poderia ter relação com o possível incremento na quantidade de bois mortos. Não é difícil deduzir um aumento no consumo de carne na Ponta Grossa na virada do século XX quando notamos que, principalmente entre os anos de 1890 e 1908, a população de Ponta Grossa aumentou em mais de 10.000 habitantes, algo que levou a cidade a ultrapassar a casa dos 15.000 moradores em fins da primeira década de 1910 (CHAVES, 2001). Não menos notável é o valor sobre a lã de carneiro. Dentre as fontes consultadas, esse é também o primeiro documento com referência a um produto da pele dos carneiros e que provavelmente provinha dos mesmos que eram abatidos no matadouro municipal e que também tinham taxação.

Quando passamos ao século XX de fato, somos remetidos a um momento que a historiografia brasileira majoritariamente trata como aquele em que os centros urbanos estavam em constante expansão e de sujeitos com olhares cada vez mais cobiçosos para com a modernidade. Seriam durante esses períodos iniciais da virada para o novo século que as cidades brasileiras dariam espaço aos bondes, praças, jardins, cafés, bares, confeitarias, hotéis, clubes, automóveis e casas comerciais. Momento referido principalmente como Belle Époque.

Ao que consta na historiografia local, no início do século XX Ponta Grossa já apresentava algumas das características dessa bela época como os bares, botequins e cafés. $\mathrm{O}$ logradouro em questão era a XV de Novembro, uma rua que concentrava os símbolos da modernidade na cidade (CHAVES; RUMBELSPERGER, 2011). Ao mesmo tempo, já havia em 
1902 as tentativas iniciais de instalar a iluminação elétrica na cidade, algo que pode ser percebido como um desejo de participar daquilo que Silva (1993) destaca como os novos fetiches do mundo capitalista, ou seja, dos símbolos que demonstravam o que existia de moderno e dinâmico nas chamadas sociedades ocidentais. Dessa forma, pode-se dizer que “o'ser ponta-grossense' do início dos Novecentos tinha nos conceitos de 'urbanidade', 'modernidade', 'progresso' e 'civilização' seus principais alicerces” (CHAVES; RUMBELSPERGER, 2011, p. 19).

Por conta de tais características, a paisagem urbana também vinha sendo modificada, visto que em 1913 o intelectual paranaense Nestor Vítor se encantava com a "Nova Ponta Grossa". Ao que indica, na alta região central a cidade já deixava para trás boa parte dos ares de vilarejo, visto que o autor de "A Terra do Futuro" comenta que naquele momento já haviam mais de 1500 casas no perímetro urbano. Casas que vieram substituir o antigo estilo colonial pelas novas de estilo eclético e platibandas ornadas, inspiradas no art-nouveau francês, no neoclássico, no gótico e em vários outros estilos arquitetônicos em moda no período (CHAVES; RUMBELSPERGER, 2011, p. 27).

A cidade se transformava, porém as práticas de matança nem tanto.

\section{A geografia urbana do matadouro}

Ao que pode ser verificado, o local de matança centralizada ficava localizado em uma região que primeiramente era composta somente por duas ruas. Uma delas era chamada naquele período de Rua Paraná ${ }^{12}$ e a outra de rua Sant'Anna, ${ }^{13}$ sendo que posteriormente nos primeiros anos do século $\mathrm{XX}$, uma viela anterior, mas de mesmo nível ao matadouro público passou a ser denominada de rua Paysandu. ${ }^{14}$ Assim, observando em uma planta (ainda que datada do final da década de 1920 e início de 1930) da cidade de Ponta Grossa, é possível "mapear" onde ficava o primeiro matadouro público da cidade de Ponta Grossa, uma vez que na documentação não há nenhuma menção ao seu endereço de fato:

\footnotetext{
${ }^{12}$ A Rua Paraná foi, posteriormente, renomeada de forma a constituir duas ruas, as quais atualmente são as Ruas Engenheiro Schamber e Rua Bonifácio Vilela. Todas as referências que faço aqui sobre a alteração ou manutenção dos nomes das ruas podem ser confirmadas no livro de nomeação de ruas da cidade de Ponta Grossa, disponível para consulta na Casa da Memória Paraná.

${ }^{13}$ Essa rua possui ainda o mesmo nome.

${ }^{14}$ Atualmente a rua se chama Penteado de Almeida.
} 


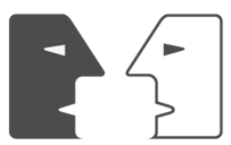

ANTÍTESES

Figura 3 - Planta da situação da cidade de Ponta Grossa -Década 1920/1930

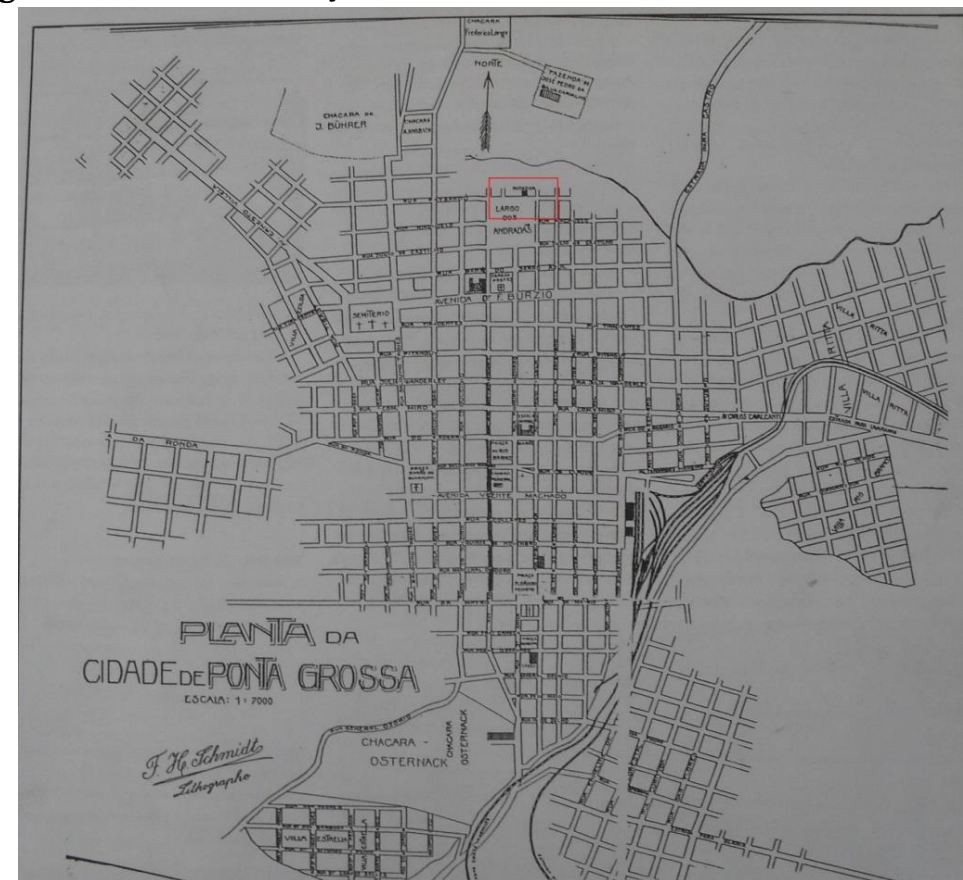

Fonte: Arquivo da Casa da Memória Paraná. Coleção do Jornal de História do Departamento de História da Universidade Estadual de Ponta Grossa.

Na imagem a seguir, temos de forma ampliada a região onde ficava o edifício:

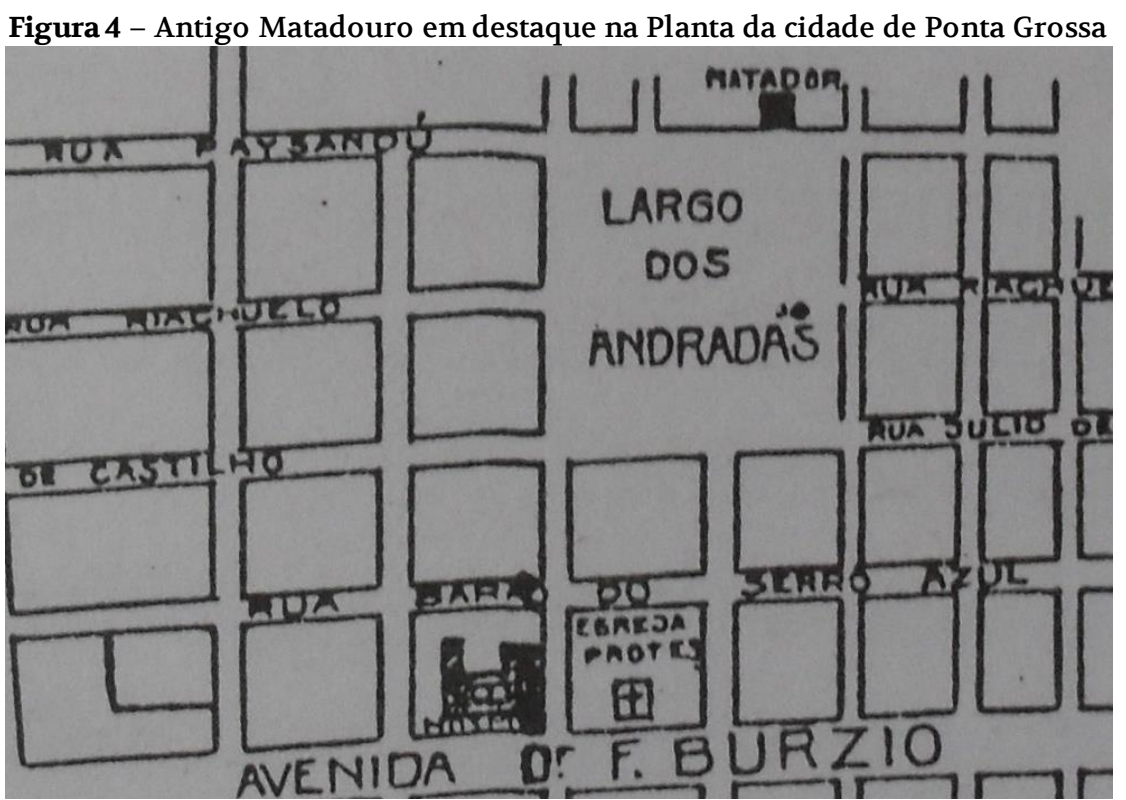

Fonte: Arquivo da Casa da Memória Paraná. Coleção do Jornal de História do Departamento de História da Universidade Estadual de Ponta Grossa. 
Antes de prosseguir, é importante ressaltar duas questões. A primeira é que a localização em questão do matadouro não consta somente na planta anteriormente destacada, ou seja, mesmo que de forma indireta, o local onde ficava estabelecido o edifício aparece em outros documentos. As fontes apontam a exclusividade que o espaço público de matança animal centralizada detinha, visto não existir informação (até os primeiros anos da década de 1930) de outro matadouro na cidade. A segunda questão seria a de como foi possível inferir essas informações.

De fato, os nomes das ruas eram diferentes do que são atualmente, bem como as legendas dos locais apresentados na planta por vezes aparecem incompletas. Neste sentido, foi necessário fazer um rápido regresso nos últimos 10 anos do XIX, período em que pudemos encontrar uma ata de 1893 com o seguinte conteúdo:

Ordem do dia

Foi lida a seguinte indicação. Indico que na rua do Paraná em direção ao Matadouro municipal, fique defronte deste terreno devoluto para um largo podendo ser concedido alem do terreno pertencente a Reynaldo Carneiro, 150 palmos ficando uma rua entre esse terreno e o que se conceder. O largo que deve ficar do espaço da rua do Commercio a rua de Sant'Anna. Paço da Camara 29 de abril de 1893. (Ata de 29 de Abril de 1893)

Nesse sentido e, conforme avançamos temporalmente na documentação, temos novos documentos. Estes são referentes à concessão e transferência de terras, nos quais constam muitas referências ao matadouro municipal e a confirmação de sua localização. Assim sendo, no que diz respeito ao ano de 1898 temos na documentação sobre concessão de terras:

28/01 Julio Meister tendo vendido a Henrique Seiler um terreno com 27 $\mathrm{m}$ e fundos correspondentes com esquinas (carta de data anexa) na rua Paraná em direção ao Matadouro, solic. ao prefeito a carta de transferência do terreno. (grifo nosso)

03/04 Paulo Krieger solicita a Camara a concessão de um terreno por carta de data de 14x33m p/ edificar anexo ao [?] Germano Krieger, atras da igreja protestante ou imediação do Matadouro anex NP 84000 reis. (grifo nosso)

03/04 Germano Krieger tendo obtido um terreno da Camara em rua sem denominação, o qual é muito úmido pois verte água em muitos 
lugares, impedindo edificação, solic a Camara um outro terreno perto do matadouro ou da igreja dos protestantes, c/ 12x33m. anx o requerimento do terreno recusado NP 72 mil reis. (grifo nosso)

[?]/04 Octavio Marcondes de Albuquerque solic a Camara um terreno por carta de data com $14 \times 33 \mathrm{~m}$ no prolongamento rua Sant Anna e esquina próximo ao matadouro.anexo NP 84 mil reis. (grifo nosso)

08/08 Balbina Schnegoosky solic . a Camara a concessão de 14 x 33 m . de terreno por carta de data para edificar uma casa na rua do Matadouro anexo ao terreno de Antonio Schenegoosky NP 84 mil reis. (grifo nosso).

Aos princípios de 1900, temos com referências ao espaço de matança as seguintes passagens:

03/10 Timotheo Souza Feijó solicita ao presidente e membros da Câmara a concessão de um terreno por carta de data para estabelecer uma xarqueada para exportar carne seca, situado a partir da magueira do matadouro em direção a vertente que divide o terreno da Baroneza de Guarauna e herdeiros que acima se enconcontra com a valla que divide os terrenos de Dona Catharina Miro e desce até os terrenos de Vicente Bonfim e seguindo para os terrenos da viúva Luiza Portella até a mangueira do matadouro. pede também a licença para matança de gado.

18/11 Octavio Marcondes de Albuquerque solicita ao prefeito passar a carta de tranferencia de terreno a Germano Kruger. Nota pagamt $20 \mathrm{mil}$ reis, carta de data do terreno a rua Sant'Anna esquina com Matadouro. (grifo nosso)

12/11 Antonio da Madureira Branco Jr tendo vendido a Germano Kruger um terreno solicita ao prefeito passar a carta de transferência para o mesmo. carta de data 1899 rua Sant'Ana próximo ao Matadouro, nota de pág 20 reis. (grifo nosso).

Já durante o ano de 1908 destacam-se os trechos: 
12/03 Balbina Chenegosck solicita ao prefeito a concessão de um terreno devoluto por carta de data para edificar uma casa para seu filho menor João Schinegosck com $14 \mathbf{~ m}$ de frente sito a rua do matadouro anexo ao terreno de Borosck e fundos com o requerido por Francisco Chinegosk . NP 77 mil reis. (grifo nosso)

08/04 Joaquim de Sousa Bueno solicita ao presidente e membros da Câmara a concessão de um terreno por carta de data devoluto para edificar uma casa com $14 \mathrm{~m}$ com fundos correspondentes sito a rua Santos Dumont alem do terreno de Luiz Silva no alto do Matadouro NP 77 mil reis

02/12 Jose Pedro Silva Carvalho pede permissão ao Presidente da Câmara para construir uma estrada para sua chácara dentro do cercado do matadouro por ser a continuação de uma rua. (grifo nosso).

E, referente à década de 1910, temos indicação do matadouro em:

01/02 Nota do agrimensor Ângelo Madallosso possui $37 \mathrm{~m}$ de excesso de terreno a rua do Matadouro, precisando legalizar. Obs. desiste do excesso em favor de outro. (grifo nosso).

A supracitada ata de 1893 faz a primeira referência à localização do matadouro municipal e também aponta para a nossa primeira coordenada de confirmação da localização. Tal documento se refere ao local o chamando explicitamente de Matadouro Municipal, ao mesmo tempo em que indica o nome de uma das ruas que direcionariam até o edifício de matança. Tais coordenadas vão se fortalecendo quando se percebe que tanto a ata quanto a documentação referente à concessão de terras revelam um traço comum a todos os requerimentos, ou seja, o de que o Matadouro Municipal era um ponto de referência da população, algo que podemos perceber nos trechos enfatizados na documentação acima reproduzida.

Mas não só isso, por vezes a rua em que ficava o edifício era indicada como rua do matadouro. Assim constatamos que a população era claramente ciente da localização daquele edifício, ou ainda, a indicação de como a existência do espaço de matança fazia parte da geografia do pontagrossense urbanizado. Soma-se ao mapeamento o fato que a localização do matadouro municipal é também confirmada pelas referências feitas a Igreja Protestante 
nos requerimentos de terras e ao traçar esses dados com a indicação do templo na planta da cidade. Por fim, se nos endereçamos mais uma vez ao livro com as nomenclaturas de ruas da cidade, que data de meados do século $\mathrm{XX}$, temos o documento mais recente com alusão à localização do antigo matadouro. Assim, é nele que encontramos a seguinte descrição sobre uma rua chamada de Santos Andrade:

\author{
Santos Andrade...... Rua \\ José Ferreira Santos Andrade \\ Formado em Direito, político brasileiro. Governador do Estado do \\ Paraná. \\ Lei nr. 42 - 10-07-1900. \\ Antigo Matadouro \\ Centro \\ ..NE
}

Se antes o livro dava direções de saber quais eram os nomes atuais das ruas, no trecho acima descrito temos o dado final da indicação de onde ficou estabelecido o primeiro matadouro municipal de Ponta Grossa. Afirmamos isso, pois o livro de nomenclaturas ao descrever a nomeação das ruas sempre estabelece alguma referência, seja ela específica ou de locais aos arredores, para melhor direcionar quem o consulta. Esse é um elemento visível no trecho acima enfatizado, o qual confirma nossa possibilidade do matadouro ter sido um importante referencial para a população ao longo de muitos anos.

Entretanto, a menção de uma Rua Santos Andrade pode, à primeira vista, mais confundir nosso mapeamento do que elucidá-lo. Porém, deve ser destacado que Ponta Grossa não possui atualmente rua alguma com esse nome, exceto uma pequena praça denominada de Santos Andrade, a qual já possui registros nos pedidos de terras do ano de 1908:

29/03 Estanislau Olijnick solicita ao presidente e membros da Câmara a concessão de um terreno por carta de data devoluto para edificar uma casa com $14 \mathrm{~m}$ de frente sito a rua que sobe a Praça Santos Andrade anexo ao terreno requerido por Bárbara Schienigosky. NP mil reis.

A Praça Santos Andrade é o local onde atualmente fica a entrada principal do prédio do Campus Central da Universidade Estadual de Ponta Grossa, sendo que este edifício está hoje 


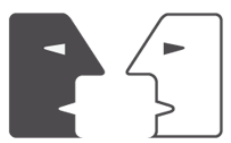

ANTÍTESES

na região destacada na figura 4 e logo abaixo da rua onde está assinalado o prédio do matadouro.

Não significa, no entanto, que o antigo local de matança centralizada fosse exatamente na denominada Rua Santos Andrade. O que é confirmado é o fato de que o livro de nomenclaturas trata do matadouro como um importante ponto de referência para aquela região e aponta para a provável localização do mesmo, algo que é fortalecido por nossas fontes.

Assim, emerge a possibilidade de que o antigo prédio do matadouro municipal ficasse onde hoje estão um estabelecimento comercial e o estacionamento do Campus Central da Universidade Estadual de Ponta Grossa. Deste modo, temos abaixo imagens atualizadas da região:

Figura 5 - Arredores atuais do antigo Matadouro Municipal e provável localização onde ficava o edifício.

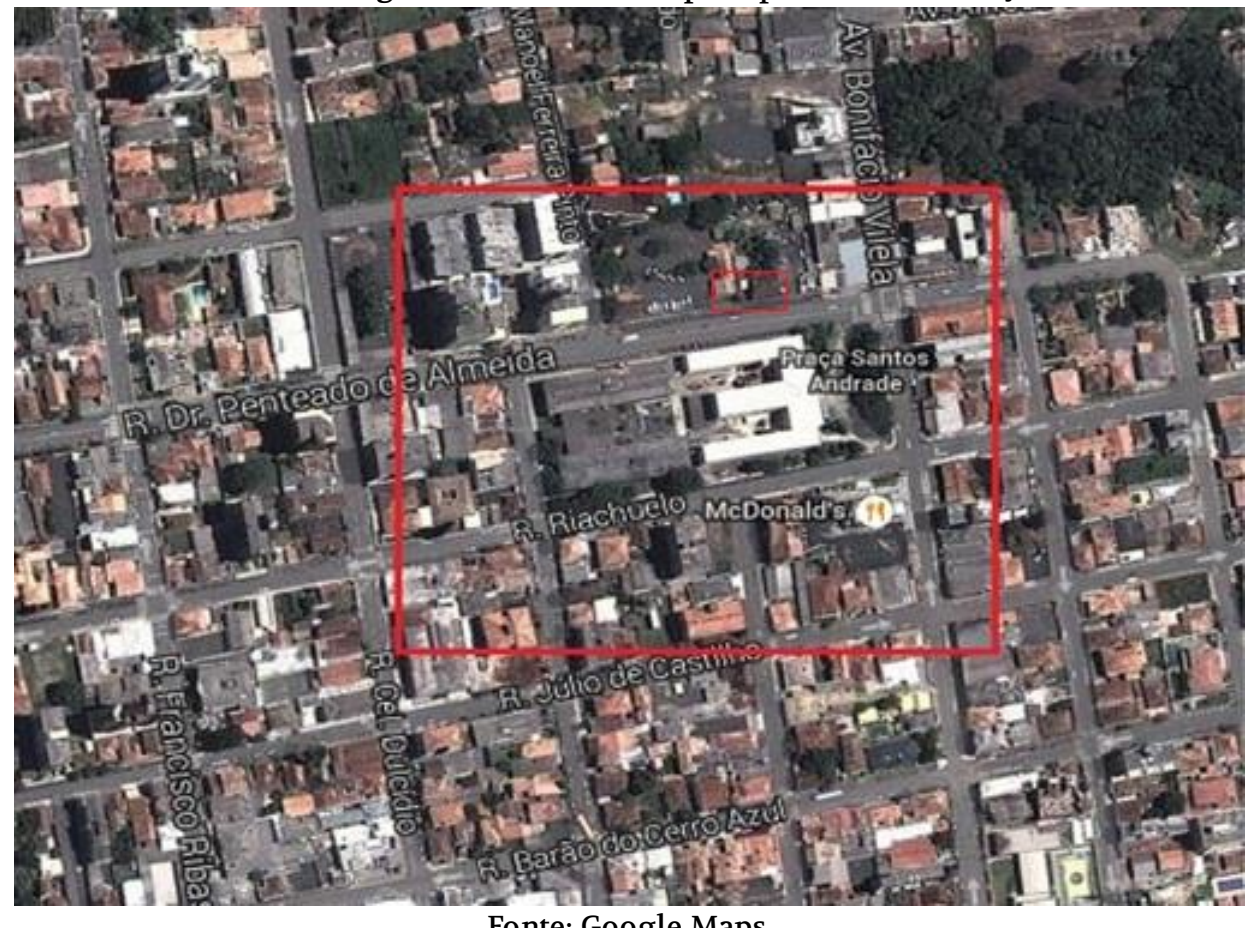

Fonte: Google Maps. 


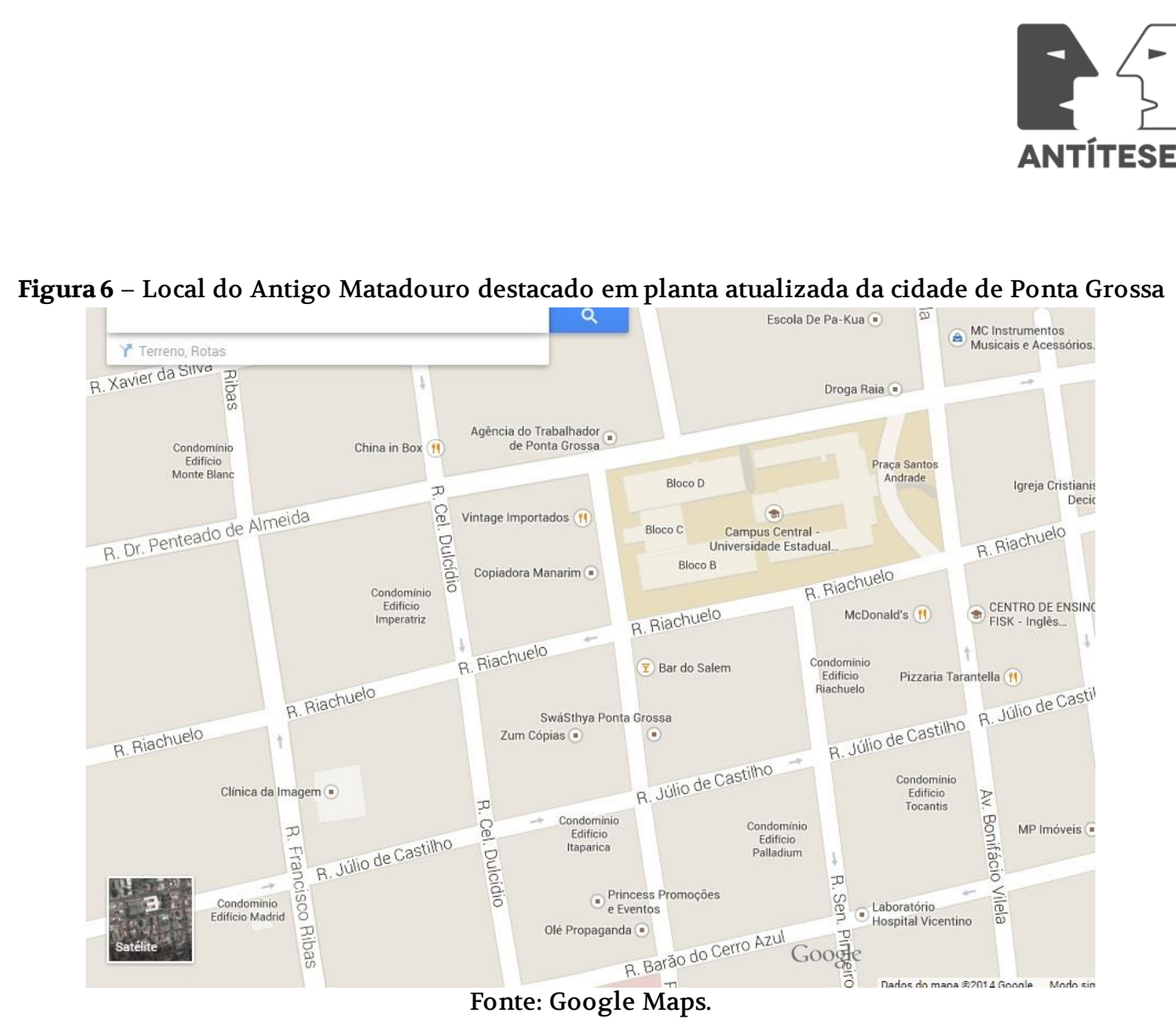

Nota-se que este matadouro público, cujas características apontam na direção de uma série de processos "pré-modernos", relacionava-se com ruas que se entrelaçavam em certa altura com um local que tinha como um dos seus principais aspectos carregar a égide da modernidade pontagrossense, neste caso a anteriormente referida rua $\mathrm{XV}$ de novembro. Essa analogia pode parecer algo realizado de forma artificial, porém chama a atenção que em um movimento de descer a rua em questão, ${ }^{15}$ um miolo de provável modernidade na cidade, e se encaminha até uma região paralela, e com uma diferença de elevação de 20 metros, encontrava-se um matadouro em plena atividade. A imagem abaixo detalha essa questão:

\footnotetext{
${ }^{15}$ Ponta Grossa é conhecida por suas ruas “desniveladas”, ou seja, a cidade se estabeleceu sobre uma grande quantidade de morros. Assim, a rua XV de Novembro é localizada emuma parte alta da cidade próxima da Igreja Matriz e também de algumas das primeiras ruas da cidade.
} 


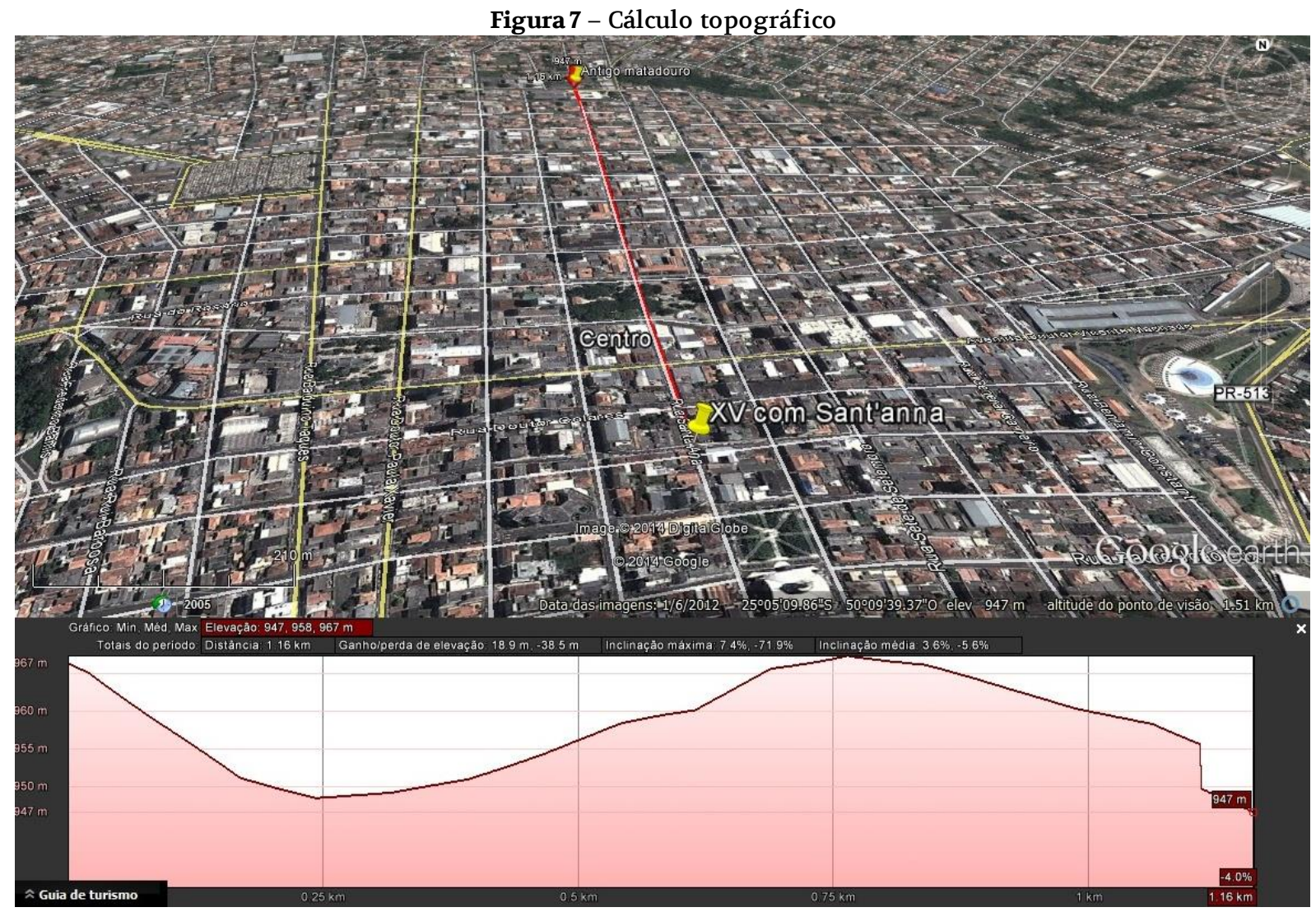

Fonte: Google Earth

Pode-se argumentar que, neste caso, a distância de pouco mais de um quilômetro entre os locais seria um fator significativo e que não haveria um embaralhamento das coordenadas na condição de existência do moderno na Ponta Grossa dos primeiros anos do século XX. Um ponto que poderia ser corroborado pela reivindicação de uma tese que é pautada na hipótese de que os sujeitos do período 1890-1930 tinham diferentes noções espaciais e do tempo que havia entre percorrer do ponto A até B, por exemplo.

Entretanto, não seria o caso de fixar-se nesse argumento, sobretudo levando em conta uma questão sobre as alterações das percepções de distâncias e nas representações de tempo pelas quais passaram os sujeitos históricos do início do século $\mathrm{XX}$, especialmente em uma cidade que vinha sendo marcada com a constante presença de trens e até do surgimento de veículos motorizados. Ainda podemos ativar a historiografia quando aponta o crescimento e a mudança das dinâmicas nas cidades, algo que também é sublinhado pela historiografia local e seu boom de urbanização, por meio da dinamização dos espaços, de um borbulhan te e moderno cotidiano repleto de "fetiches" capitalistas que chegavam pelas estradas de ferro, a disseminação dos postes com iluminação elétrica e do então aumento demográfico (CHAVES, 2001; CHAVES; RUMBELSPERGER, 2011; PETUBA, 2011; SILVA, 1993). 
O que pode ser inferido é que a distância de cerca de mais de mil metros talvez fora significativa por algum tempo, mas poderia ser problematizada em relação aos itens anteriormente apontados e em relação aos sujeitos que viveram a virada e os princípios do século XX. Parece-nos que os habitantes da época viveram em um período intermediário em que, apesar de toda a incrementação pelo qual o espaço urbano de Ponta Grossa vinha passando (e que à primeira vista poderia ser corroborada pela modernidade de se ter um matadouro municipal), existia um local de matança próximo, com as condições de funcionamento aqui já discutidas, coexistindo com uma vida urbana de significativa movimentação. Características também evidenciadas ao perceber que, na documentação de transferência e concessão de terras, parte da população habitava ou buscava edificar residências nas proximidades do matadouro municipal.

\section{Considerações finais}

O matadouro funcionou neste local até ser transferido, em 1936, para o novo prédio construído afastado da zona urbana. Hoje em dia poucos sabem que o matadouro municipal ficava onde agora é praticamente o centro da cidade. Na memória do tempo presente é a imagem e a localização do segundo edifício do matadouro, o do bairro de Uvaranas interditado recentemente, em Outubro de 2013 por ter funcionado sem licença ambiental, de maneira irregular - que prevalecem. Aliás, apenas uma historiadora sênior, a doutora Aída Mansani Lavalli, nos afirmou, numa conversa informal, lembrar da localização do antigo matadouro como sendo de fato onde mapeamos.

De toda forma, é interessante tratar de todas essas faces da cidade guardando algo que poderíamos chamar de proporções e respeito a certas singularidades históricas no que toca aos discursos enunciados sobre a modernidade e o progresso de Ponta Grossa. Entretanto, como a historiografia constantemente busca evocar tais conceitos para tecer a historicidade da cidade, evidenciar a presença do matadouro nesse espaço e notar que o mesmo vinha a constituir parte da paisagem urbana dá corpo a novas e instigantes formas de pensar não só a cidade, mas também as próprias narrativas históricas (acadêmicas ou não) com seus discursos e representações sobre Ponta Grossa, bem como amplia o escopo teóricometodológico da análise. 


\section{Fontes Documentais}

Ata da $6^{\circ}$ sessão ordinária de 29 de Abril de 1893.

Ata da sessão de fevereiro de 1898.

Ata da sessão extraordinária de 10 de março de 1894.

Ata da sessão ordinária de 20 de dezembro de 1897.

Atas da Câmara Municipal

Ata da $4^{\circ}$ sessão em 19 de Janeiro de 1893.

\section{Referências}

CHAVES, Niltonci Batista, RUMBELSPERGER, Robson. Os botequins da Belle Époque pontagrossense: lazer e sociabilidade no interior paranaense no início do século XX. Ponta Grossa: Estúdio Texto, 2011.

CHAVES, Niltonci Batista. A cidade civilizada: discursos e representações sociais no Jornal Diário dos Campos. Curitiba: Aos Quatro Ventos, 2001.

ERICHSEN, Lucas; CARVALHO, Alessandra Izabel. O matadouro municipal de Ponta Grossa e a historicidade da matança animal, centralizada no fim do século XIX. Diálogos, Maringá, v. 18, supl., p. 155-178, dez. 2014.

LAPA, José Roberto do Amaral. A cidade: os cantos e os antros: Campinas 1850-1900. São Paulo: Universidade de São Paulo, 1996.

MACLACHLAN, Ian. A bloody offal nuisance: the persistence of private slaughterhouses in nineteenth-century London. Urban History, Cambridge, v. 34, n. 2, p. 227-254, Aug. 2007.

NIERADZIK, Lukasz. Butchering and the transformation of work in the19th century: the viennese slaughterhouse saint marx. International Journal of Humanities and Social Science, Los Angeles, v. 2, n. 17, p. 12-16, Sept. 2012. 
OTTER, Chris. The vital city: public analysis, dairies and slaughterhouses in nineteenth century Britain. Cultural Geographies, London, v. 13, p. 517-537, 2006.

PEREIRA, M. R. M. O centauro desfeito. A desconstrução da cultura gaúcha do Paraná no século XIX. Anuário de História de América Latina, Koln, n. 36, p. 197-218, 1999.

PETUBA, Rosangela Maria Silva. Na trama dos trilhos: cidade, ferrovia e trabalho - Ponta Grossa - PR (1955-1997). 2011. Tese (Doutorado em História) - Universidade Federal de Santa Catarina, Florianópolis, 2011.

SEGATA, Jean. A agência de um projeto, o paraíso vegetariano e outros inconvenientes com a humanidade dos animais de estimação na Antropologia. Revista Anthropológicas, ano 17, v. 24, n. 1, p. 45-65, 2013.

SILVA, Edson Armando. Energia elétrica e desenvolvimento industrial em PontaGrossa 1904-1973. 1993. 196 f. Dissertação (Mestrado em História do Brasil) - Universidade Federal do Paraná, Curitiba, 1993.

Recebido em 22/08/2016

Aprovado em 24/03/2017 